\title{
Aleksandra M. Kollontaj. Diplomatiske nedtegnelser 1922-1930
}

Åsmund Egge, Sven. G. Holtsmark \& Aleksej A. Komarov (red.)

Oslo: Res Publica 2015

842 sider. ISBN 9788282260398

Anmeldt av Kari Aga Myklebost [Barents Chair in Russian Studies, UiT Norges arktiske universitet, kari.myklebost@uit.no]

Aleksandra Kollontaj (1872-1952) var en ukonvensjonell og svært synlig figur i sin tid, og hennes memoarer fra årene som diplomat for sovjetregjeringen i Norge utgiør spennende lesning. Som glødende feminist, fredsaktivist, forfatter, politisk agitator, del av bolsjevik-fraksjonen i Det russiske sosialdemokratiske arbeiderpartiet fra 1915, medlem av bolsjevikenes regjering etter oktoberrevolusjonen i 1917 og verdens første kvinnelige ambassadør fra 1924, vakte hun oppsikt.

I Norge pleide hun kontakt med sentrale figurer på venstresiden i politikk og kulturliv, og i årene fram mot utnevnelsen som diplomat opparbeidet hun seg et nettverk som omfattet blant andre Martin Tranmæl, Rachel og Kyrre Grepp, Edvard Bull, Ellisif Wessel, Adam Egede-Nissen og Olav Scheflo. Disse forsynte Kollontaj med informasjon om utviklingen $\mathrm{i}$ norsk politikk $\mathrm{i}$ en periode da bolsjevikene anså nettopp den norske arbeiderbevegelsen som en nøkkelalliert i mobiliseringen av revolusjonære krefter. Slik sett var Kollontaj på rett sted til rett tid - selv om foranledningen til at hun ble stasjonert i Kristiania var at den såkalte "arbeideropposisjonen» innenfor bolsjevikpartiet, som Kollontaj hadde tilhørt, led nederlag på partikongressen i 1921. Kollontaj ønsket seg bort fra den sentrale partipolitikken, og ble sendt til Norge for å arbeide i den sovjetrussiske handelsdelegasjonen der. Hun ble ambassadør eller såkalt befullmektiget representant fra 1924, da fulle diplomatiske forbindelser ble opprettet mellom Norge og Sovjetunionen. Hun utviste stor diplomatisk manøvreringsevne og fikk i havn viktige avtaler mellom sovjetiske og norske myndigheter. I norsk presse ble Kollontaj portrettert som en innflytelsesrik skikkelse. Før stortingsvalget i 1924 ble hun avbildet arm i arm med Venstre-mann og utenriksminister Johan Ludwig Mowinckel, med en fornøyd Olaf Scheflo i miniatyr i den ledige hånden.

Kollontajs diplomatiske nedtegnelser gir innblikk i en rekke sentrale forhold i norsk og sovjetrussisk historie på 1920-tallet, som blant annet splittelsen i den norske arbeiderbevegelsen og forholdet til Den kommunistiske internasjonale, spenninger rundt grenselinjer og fangst i Nordishavet, forsøkene på å få i stand en norsksovjetisk sikkerhetspakt - og det Kollontaj selv betegnet som sine to største suksesser som diplomat i Norge: den norske de jure anerkjennelsen av sovjetregjeringen og 
framforhandlingen av en handelsavtale mellom de to landene. I tillegg inneholder teksten nedtegnelser fra Kollontajs periode som ambassadør til Mexico 1926-1927. Bokas innledning er en fyldig og informativ biografisk artikkel med hovedvekt på Kollontajs år i Norge og fungerer som et svært godt rammeverk for å forstå hendelsene som beskrives i nedtegnelsene. Her kan leseren nyte godt av redaktørenes brede kunnskaper om norsk-sovjetiske relasjoner i perioden og deres oversikt over og egne bidrag til tidligere forskning på Kollontaj.

Nedtegnelsene framstår i en språklig gjennomarbeidet form, og det er ikke tvil om at de to oversetterne Dina Roll-Hansen og Steinar Gil har lagt ned et stort arbeid i teksten. Boka inneholder også et nyttig register med mini-biografier over personer som er nevnt i nedtegnelsene, samt et innstikk midt i boka med fotografier fra Kollontajs liv. Mange av disse er sterke uttrykk for hvordan Kollontaj både ble framstilt og ønsket å framstå i offentligheten. Ofte som en hardt arbeidende diplomat bak skrivebordet, men i mange tilfeller også stilfullt kledt på ulike representasjonsoppdrag - og stort sett omgitt av menn.

Det kanskje mest spennende og samtidig vanskeligste aspektet ved memoarene er deres tilblivelseshistorie. Dette drøftes utførlig av redaktørene i bokas innledning. De diplomatiske nedtegnelsene som nå foreligger i norsk språkdrakt er basert på en redigert, maskinskrevet tekst som Kollontaj overleverte til Marx-Engels-Lenininstituttet i Moskva i 1952. Da hadde hun trolig brukt fire år - fra sommeren 1947 til høsten 1951 - på å redigere og skrive ut memoarene, som var basert på hennes løpende notater fra årene som diplomatisk representant. Vi har altså å gjøre med en «frisert» tekst hvor både erindringsforskyvelser og politiske konjunkturer trolig har spilt en stor rolle i å frambringe den endelige versjonen - uten at vi vet hvor sterk omarbeidingen har vært.

Tidligere forskning har konkludert med at memoarene er en stilistisk forbedret versjon av Kollontajs dagboknotater uten substansielle innholdsmessige forandringer. Redaktørene av den norske utgaven konkluderer i motsatt retning og understreker hvordan det politiske klimaet i Sovjetunionen i årene etter andre verdenskrig må antas å ha fordret en politisk korrekt versjon av nedtegnelsene - en som Kollontaj selv og hennes familie kunne leve med i stedet for å dø av, slik svært mange sovjetiske diplomater gjorde under Stalins regime. Redaktørene drøfter flere eksempler som alle underbygger antakelsen om at teksten har vært underlagt kraftig bearbeidelse fra Kollontajs hånd (se for eksempel s. 19 om Kollontajs innflytelse på lederne i Det norske Arbeiderpartis ungdomsbevegelse, s. 32 om hennes rolle i å forebygge splittelsen i DnA i 1923). I tillegg peker redaktørene på åpenbare feilerindringer som indikerer at deler av teksten er skrevet ut lenge etter 20-tallet (for eksempel s. 75-77). Selvmotsigelser - enkelte steder fordømming av dødsstraff som politisk verktøy, andre steder forsvar av det samme - viser hvordan teksten har blitt til i spennet mellom opplevd fortid, erindring og krav om politisk korrekthet $i$ tida da nedtegnelsene skulle overleveres til de sovjetiske arkivene.

De diplomatiske nedtegnelsene reflekterer altså flere lag i tid, og det er mye som taler for at årene 1947-1951 har preget teksten vel så mye som 1920-tallet. Redaktørene skriver at nedtegnelsene først og fremst må leses som et politisk-diplomatisk 
erindringsskrift, et uttrykk for «hva Kollontaj ønsket at leseren (les: Stalin) skulle tro at hun hadde ment» i årene som diplomat i Norge. Dette gjør på et vis teksten mer innholdsrik eller mangefasettert - samtidig som det gjør bruken av den som historisk kilde mer arbeidskrevende. Innførslene i nedtegnelsene krever grundig kontekstualisering.

Det forblir en gåte hvordan Kollontaj personlig, som menneske, forholdt seg til konflikten mellom det stadig hardere regimet under Stalin og egne relativt sett liberale og humanistiske politiske holdninger. Kollontaj var ingen hardliner - men hun overlevde maktkamp og utrenskninger som rammet svært mange andre sovjetiske diplomater. De redigerte dagboksnotatene, skrevet for Stalins og ettertidens øyne, er et uttrykk for hvordan hun manøvrerte gjennom den farlige sen-stalinismen. 